\title{
APLIKASI EKSTRAK ABU SABUT KELAPA SEBAGAI BAHAN PENGENYAL DAN PENGAWET ALAMI DALAM PEMBUATAN MIE BASAH
}

\section{APPLICATION OF COCONUT COIR ASH EXTRACT AS A NATURAL PRESERVATIVE AND CHEWINESS AGENT IN WET NOODLES}

\author{
Rachmad Abraham Firdaus ${ }^{1}$, Rohula Utami ${ }^{1}$, Edhi Nurhartadi ${ }^{1}$ \\ ${ }^{1}$ Program Studi Ilmu dan Teknologi Pangan, Universitas Sebelas Maret Surakarta \\ email: rabrahamf@gmail.com
}

\begin{abstract}
Many use of illegal preservative and chewiness agent from year to year to encourage to seek alternative of natural preservatives and chewiness agent. In the process of making wet noodles generally used synthetic agent to improve the level of chewiness and extend the shelf life of wet noodles. This research was created to make an alternative of natural preservatives and chewiness agent which replaced the synthetic preservatives and chewiness agent. The aim of this research is to know the influence of the substitution of coconut coir ash extract used in the making of wet noodles in the levels of 10\%, 20\%, and 30\% against the level of chewy (firmness and elasticity), chemical characteristics $\left(A_{w}\right.$ and $\left.\mathrm{pH}\right)$, and the ability to inhibit the growth of microbes in a wet noodle. Analysis of level of chewy and $A_{w}$ in wet noodle was performed at the 0 , whereas the pH measurement and microbiological analysis was performed at the hour 0, 24, and 48.

Results showed that the concentration coconut coir ash extract in levels of 30\% has the lowest level of firmness, that is 7852,300 gforce, the highest level of elasticity. 21,570 gforce with $A_{w}$ of 0,907; as well as having a pH in hour 0, 24, and 48 was 9,23; 8,99; and 8,30. While the number of microbes on the hour 0, 24, and 48 is 2,22; 4,95; and 6,59 $\log \mathrm{CFU} / \mathrm{g}$. This indicates that the coconut coir ash extract could inhibit microbial growth rate by pressing the $A_{w}$ and $\mathrm{pH}$ in alkaline conditions were set.
\end{abstract}

Keywords: natural chewiness agent, natural preservative agent, coconut coir ash, wet noodles

\section{ABSTRAK}

Maraknya penggunaan bahan pengenyal dan pengawet ilegal dari tahun ke tahun memotivasi untuk mencari alternatif bahan pengenyal dan pengawet. Pada proses pembuatan mie basah umumnya memakai bahan-bahan sintetis untuk meningkatkan kekenyalan dan memperpanjang umur simpan mie basah. Oleh karena itu, penelitian ini dibuat untuk memberi solusi alternatif bahan pengenyal dan pengawet alami untuk menggantikan bahan-bahan pengenyal dan pengawet sintetis. Tujuan dari penelitian ini adalah untuk mengetahui pengaruh substitusi ekstrak abu sabut kelapa pada air yang digunakan dalam proses pembuatan mie basah dengan variasi kadar 10\%, 20\%, dan 30\% terhadap tingkat kekenyalan (kekerasan dan elastisitas), karakteristik kimia $\left(\mathrm{A}_{\mathrm{w}}\right.$ dan $\mathrm{pH})$, dan kemampuan menghambat pertumbuhan mikroba dalam mie basah. Analisa tingkat kekenyalan dan $\mathrm{A}_{\mathrm{w}}$ mie basah dilakukan pada jam ke-0, sedangkan untuk pengukuran $\mathrm{pH}$ dan analisa mutu mikrobiologis dilakukan pada jam ke-0, 24, dan 48 .

Hasil meninjukkan bahwa konsentrasi substitusi ekstrak abu sabut kelapa terhadap air dengan variasi kadar 30\% memiliki tingkat kekerasan terendah, yaitu 7852,300 gforce, tingkat elastisitas tertinggi yaitu 21,570 gforce dengan $\mathrm{A}_{\mathrm{w}}$ sebesar 0,907; serta memiliki pH pada jam ke 0, 24, dan 48 sebesar 9,23; 8,99; dan 8,30. Sedangkan jumlah mikroba pada jam ke-0, 24, dan 48 sebesar 2,22; 4,95; dan 6,59 log CFU/g.

Kata Kunci : pengenyal alami, pengawet alami, abu sabut kelapa, mie basah

\section{PENDAHULUAN}

Mi merupakan salah satu jenis makanan yang populer di Asia khususnya di Asia Timur dan Asia Tenggara. Di Indonesia, banyak orang mengkonsumsi mi karena rasanya yang disukai dan praktis dalam penyajiannya. Mi sering dijadikan pangan alternatif pengganti nasi sebagai penghasil energi karena kandungan karbohidratnya yang tinggi (Kruger dan Robert, 1996).Produksi mi basah di Indonesia cukup besar. Menurut Badan Pusat Statistik, data produksi mi basah di Indonesia pada tahun 2002 sebesar $92.492 .696 \mathrm{~kg}$, sedangkan data konsumsi mi basah penduduk Indonesia pada tahun 2004 untuk pengeluaran rata-rata perkapita dalam seminggu adalah $0,140 \mathrm{~kg}$. 
Artinya konsumsi mi basah setiap penduduk Indonesia dalam seminggu adalah 140 gram mi basah.

Kadar air mi basah yang cukup tinggi serta kondisi sanitasi proses produksi, peralatan dan perilaku pekerja yang kurang terjamin kebersihannya menyebabkan mi basah cepat mengalami kerusakan akibat pertumbuhan mikroba seperti kapang, khamir dan bakteri yang cukup tinggi. Pada mi basah matang kerusakan terjadi setelah 40 jam pada suhu kamar berupa tumbuhnya kapang (Hoseney, 1998). Saat ini usaha yang dapat dilakukan oleh produsen untuk menghambat pertumbuhan mikroba dan memperpanjang umur simpan mi basah adalah dengan melakukan penambahan bahan pengawet. Akan tetapi seringkali bahan pengawet yang ditambahkan bukanlah pengawet untuk makanan.

Produsen mi sering menggunakan bahan yang dilarang seperti formalin dan boraks sebagai pengawet pada mi basah. Hasil pengujian Badan POM dari sampling dan pengujian laboratorium secara serentak di Bandar Lampung, Jakarta, Bandung, Semarang, Yogyakarta, Surabaya, Mataram, dan Makasar pada Desember 2005 menunjukkan bahwa $64,32 \%$ mi basah tidak memenuhi syarat kesehatan karena mengandung formalin. Selain itu, Badan POM juga melaporkan, dari 24 sampel yang diuji, lebih dari $80 \%$ mi basah yang dijual di Pasar Bandung mengandung boraks dan formalin (Putra, 2007). Alasan produsen menggunakan formalin dan boraks sebagai bahan pengawet adalah karena harga yang murah, lebih awet, dan mutu mi basah yang dihasilkan lebih bagus (Astawan, 2006).

Berdasarkan hasil penelitian Oktaviani (2005), banyak kejadian penggunaan bahan aditif berbahaya (seperti boraks dan formalin) sebagai bahan pengawet makanan. Zat aditif tersebut biasanya dicampurkan pada makanan dengan tujuan meningkatkan sifat fisik dari produk makanan sehingga memberikan kekenyalan. Penambahan boraks sebanyak $300 \mathrm{ppm}$ dapat meningkatkan elastisitas mie dari 22,5 gforce menjadi 31,96 gforce.

Langkah Pahrudin (2006) dalam mencari zat aditif yang rendah akan efek yang bersifat akut dan kronik, perlu diapresiasi. Pengawet yang digunakan adalah metil paraben, kalsium propionat, natrium asetat, dan monolaurin. Namun pengawet sintesis yang digunakan cenderung menghasilkan kualitas mie yang kurang diminati konsumen. Langkah mencari berbagai teknik produksi mie perlu dilakukan dalam rangka mengurangi efek dari zat aditif yang sarat resiko ini.

Penelitian mengenai pembuatan mie basah dengan mengganti sumber kalium karbonat dan natrium karbonat sebagai bahan pengenyal sudah pernah dilakukan. Penelitian Polii (2003) mengganti soda abu $\left(\mathrm{Na}_{2} \mathrm{CO}_{3}\right)$ dengan abu sabut kelapa, dan didapatkan hasil uji organoleptik tekstur mie basah yang disukai konsumen dengan penambahan konsentrasi abu sabut kelapa $200 \mathrm{mg} / \mathrm{kg}$ berat tepung terigu. Namun pada variasi konsentrasi abu sabut kelapa yang lebih tinggi yaitu $20 \mathrm{~g} / \mathrm{kg}$ berat tepung terigu, tekstur mie basah yang dihasilkan justru lebih rendah daripada kontrol. Abu sabut kelapa yang digunakan dalam penelitian tersebut adalah dalam bentuk padat (hablur/kristal abu sabut kelapa) dan cair (air rendaman abu sabut kelapa/larutan abu sabut kelapa). Polii (2003) hanya melakukan uji organoleptik terkait dengan tekstur mie basah, namun tidak mencantumkan data perbedaan sampel tekstur mie basah tersebut secara kuantitatif.

Penelitian ini merupakan suatu upaya penggantian penggunaan bahan pengenyal dan pengawet sintetis terhadap makanan oleh bahan pengenyal dan pengawet alami yang lebih aman dikonsumsi serta dalam rangka meningkatkan kualitas makanan yang dibutuhkan oleh tubuh.

\section{METODE PENELITIAN}

\section{Bahan dan Alat}

Bahan-bahan yang digunakan pada penelitian ini terbagi menjadi tiga yaitu bahan untuk ekstraksi abu sabut kelapa, pembuatan mie basah, dan analisis. Bahan yang digunakan untuk ekstraksi sabut kelapa adalah sabut kelapa dan aquades. Bahan yang digunakan dalam pembuatan mie basah meliputi tepung terigu merk Cakra Kembar dan aquades. Sedangkan bahan untuk analisis 
di antaranya adalah $\mathrm{NaCl}$, media PCA (Plate Count Agar), dan alkohol 70\%.

Alat-alat yang digunakan juga dibagi menjadi tiga bagian, yaitu alat untuk ekstraksi abu sabut kelapa, pembuatan mie basah dan alat untuk analisis, baik analisis fisik, kimia, ataupun mikrobiologi. Alat-alat yang digunakan untuk ekstraksi abu sabut kelapa meliputi tanur, timbangan, gelas ukur, elenmeyer, dan pengaduk. Alat-alat yang digunakan dalam produksi mie adalah mesin pencetak mie, timbangan, baskom, gelas ukur, elenmeyer, labu ukur, dan pipet. Alatalat yang digunakan untuk analisis adalah mortar, cawan petri steril, tabung reaksi, pipet, mikropipet, inkubator, bunsen, elenmeyer, gelas ukur, beaker glass, stirrer, $\mathrm{A}_{\mathrm{w}}$-meter Shibaura WA-360, pH-meter Walk, dan texture analyzer merk Test Zwick.

\section{Tahapan Penelitian}

1. Persiapan Ekstrak Abu Sabut Kelapa

a. Pengeringan

Mula-mula sabut kelapa yang didapat dikeringkan terlebih dahulu selama 1 hari dengan cara dijemur di bawah sinar matahari langsung. Hal ini berfungsi untuk mengurangi kadar air yang mungkin terkandung di dalam sabut kelapa karena faktor eksternal, misalnya air hujan, embun, dan lain-lain, serta memastikan bahwa sabut kelapa benarbenar kering agar proses pengabuan berjalan maksimal.

b. Pengabuan

Tahapan berikutnya adalah pengabuan. Abu sabut kelapa didapatkan dari proses pembakaran sempurna sabut kelapa hingga didapatkan abu (bukan arang). Proses ini pengabuan ini dilakukan dengan tanur pada suhu $500^{\circ} \mathrm{C}$ selama 3 jam.

c. Ekstraksi

Setelah didapatkan abu sabut kelapa, proses berikutnya adalah ekstraksi abu sabut kelapa dengan cara merendamabu sabut kelapa dalam air dengan perbandingan 1:50 pada tabung elenmeyer selama 48 jam. Pada tahap ini akan terbentuk endapan abu sabut kelapa di bagian bawah dan air bening di bagian atas. Proses ekstraksi ini berfungsi untuk melarutkan mineral-mineral yang terkandung dalam abu sabut kelapa ke dalam air, termasuk unsur kalium dan natrium. Menurut Agra (1974) jumlah kalium yang terekstrak optimal adalah dengan melarutkan 1 gr abu ke dalam 50 $\mathrm{ml}$ air dan disimpan pada suhu ruang.

d. Penyaringan

Setelah perendaman selama 48 jam, air bening yang berada di bagian atas rendaman abu sabut kelapa diambil dan disaring sebanyak satu kali pernyaringan menggunakan kertas saring, sehingga didapatkan ekstrak cair abu sabut kelapa.

2. Persiapan Pembuatan Mie Basah dengan Substitusi Ekstrak Abu Sabut Kelapa

a. Pencampuran

Proses pembuatan mie basah dilakukan dengan mencampurkan bahan baku tepung terigu $50 \mathrm{gr}$, air (aquades) 40\% dari bobot tepung, dan substitusi ekstrak abu sabut kelapa menjadi satu dimaksudkan untuk membuat adonan yang homogen. Proses ini menggunakan variasi perlakuan substitusi ekstrak abu sabut kelapa terhadap air dengan kadar $0 \%, 10 \%, 20 \%$, dan $30 \%$.

b. Pengadukan

Ada beberapa hal yang perlu diperhatikan dalam pembuatan mie basah yaitu suhu adonan, waktu pengadukan, jumlah air yang ditambahkan. Waktu pencampuran dan pengadukan bahan dilakukan selama 15 menit. Menurut Badrudin (1994), waktu pengadukan terbaik adalah 15 hingga 25 menit. Apabila waktu pengadukan kurang dari 15 menit, adonan akan menjadi lunak dan lengket, sedangkan jika lebih dari 25 menit adonan akan menjadi keras, rapuh, dan kering.

c. Pembentukan lembaran

Tahap selanjutnya adalah pembentukan lembaran. Proses ini bertujuan untuk menghaluskan serat-serat gluten dan membentuk adonan menjadi lembaran (Badrudin, 1994). Lembaran yang diharapkan berupa lembaran yang halus dengan arah serat searah.

d. Pengistirahatan 
Lembaran selanjutnya diistirahatkan selama 15 menit pada suhu ruang dan sebaiknya dalam keadaan digulung dan dibungkus plastik. Tujuan pengistirahatan adalah untuk menyempurnakan pembentukan gluten.

e. Penipisan dan pemotongan lembaran

Setelah diistirahatkan, pemotongan lembaran dilakukan dengan memotong mie menjadi untaian benang-benang mie yang memiliki tebal 1-3 mm.

f. Penaburan mie dengan tapioka

Setelah dicetak, untaian benang mie ditaburi dengan tepung tapioka agar tidak lengket satu sama lain.

\section{HASIL DAN PEMBAHASAN}

\section{Kekerasan (Firmness)}

Berdasarkan Gambar 4.1, sampel kontrol memiliki nilai tekstur kekerasan ratarata sebesar 10083,940 gforce; sampel dengan substitusi ekstrak abu sabut kelapa $10 \%$, 20\%, dan 30\% berturut-turut memiliki nilai tekstur kekerasan rata-rata 10038,335 gforce; 9253,125 gforce; dan 7852,300 gforce. Dalam penelitian ini mie basah kontrol memiliki tingkat kekerasan tertinggi yaitu sebesar 10083,940 gforce; sedangkan mie basah dengan substitusi ekstrak abu sabut kelapa 30\% memiliki tingkat kekerasan terendah yaitu sebesar 7852,300 gforce.

Sampel mie dengan substitusi ekstrak abu sabut kelapa memiliki tekstur yang lebih lunak daripada sampel kontrol. Semakin banyak ekstrak abu sabut kelapa yang dihasilkan maka tekstur mie basah yang dihasilkan juga semakin lunak. Menurut Astawan (1999), STPP dan $\mathrm{Na}_{2} \mathrm{CO}_{3}$ memiliki kemampuan untuk mengikat air yang terdapat dalam adonan pembuatan mie. Penambahan senyawa alkali selama pembuatan adonan akan menyebabkan proses penyerapan air menjadi lebih cepat. Reaksi senyawa alkali dengan pati dan air akan menghasilkan $\mathrm{CO}_{2}$ sehingga terbentuk rongga antar ruang granula pati. Alkali akan melepas ikatan sehingga air dapat melakukan penetrasi ke dalam granula pati, sehingga air tidak mudah menguap dan tidak menyebabkan permukaan adonan menjadi kering dan keras sebelum proses pembentukan adonan. Reaksi adalah sebagai berikut :

$$
\begin{aligned}
& \mathrm{Na}_{2} \mathrm{CO}_{3}+\mathrm{H}_{2} \mathrm{O} \rightarrow 2 \mathrm{NaOH}+\mathrm{CO}_{2} \\
& \mathrm{~K}_{2} \mathrm{CO}_{3}+\mathrm{H}_{2} \mathrm{O} \rightarrow 2 \mathrm{KOH}+\mathrm{CO}_{2} \\
& \mathrm{CO}_{2}+\mathrm{H}_{2} \mathrm{O} \rightarrow \mathrm{H}_{2} \mathrm{CO}_{3}
\end{aligned}
$$

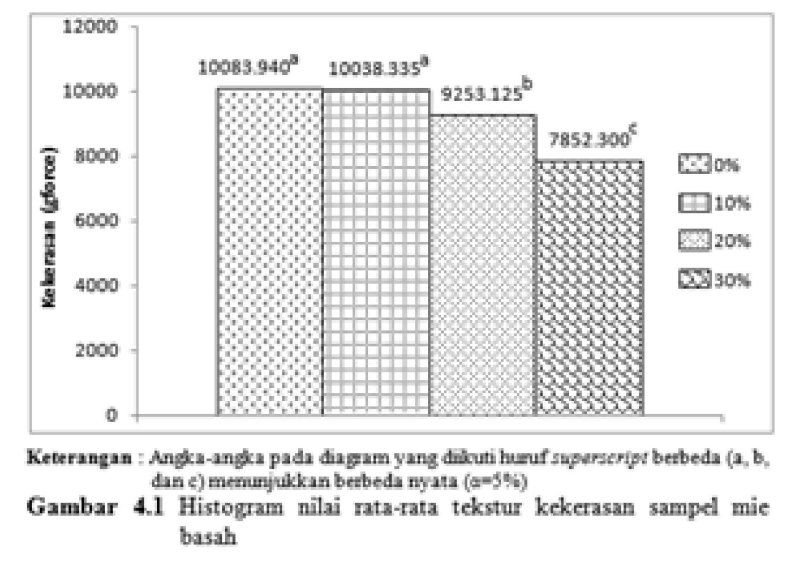

Elastisitas

Berdasarkan Gambar 4.2, nilai elastisitas rata-rata sampel kontrol sebesar 12,355 gforce, sedangkan nilai elastisitas rata-rata sampel substitusi $10 \%, 20 \%$, dan $30 \%$ berturut-turut sebesar 13,170 gforce; 17,705 gforce; dan 21,570 gforce. Dalam penelitian ini, sampel kontrol memiliki tingkat elastisitas yang paling rendah yaitu sebesar 12,355 gforce, sedangkan sampel substitusi 30\% memiliki tingkat elastisitas paling tinggi yaitu sebesar 21,570 gforce.

Gambar 4.2 menunjukkan bahwa adanya pengaruh substitusi ekstrak abu sabut kelapa terhadap elistisitas mie basah yang dihasilkan.

Semakin besar kadar ekstrak abu sabut kelapa yang disubstitusikan ke dalam mie basah, maka tingkat elastisitas yang dihasilkan pun semakin besar, sehingga mie basah tidak mudah putus.

Adanya senyawa $\mathrm{Na}_{2} \mathrm{CO}_{3}$ dan $\mathrm{K}_{2} \mathrm{CO}_{3}$ yang terdapat pada ekstrak abu sabut kelapa diduga mampu membantu meningkatkan elastisitas mie basah. Menurut Badrudin (1994) garam alkali yang bisa terdiri atas kalium karbonat $\left(\mathrm{K}_{2} \mathrm{CO}_{3}\right)$, natrium karbonat $\left(\mathrm{Na}_{2} \mathrm{CO}_{3}\right)$ atau kalium polifosfat $\left(\mathrm{K}_{2} \mathrm{PO}_{4}\right)$ berfungsi untuk meningkatkan $\mathrm{pH}$, menyebabkan warna sedikit kuning dengan flavor yang lebih baik. Secara khusus, natrium karbonat lebih berperan untuk kehalusan tekstur, kalium karbonat untuk 
meningkatkan kekenyalan sedangkan kalium polifosfat untuk meningkatkan elastisitas dan fleksibilitas mie.

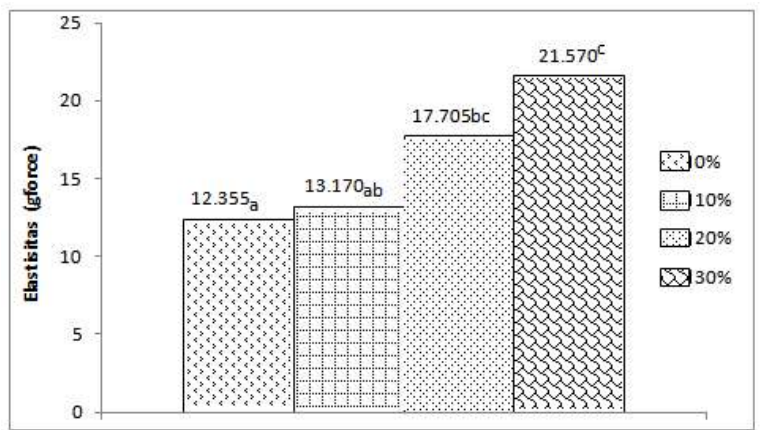

Keterangan : Angka-angka pada diagram yang diikuti hunuf superscript berbeda (a, b, dan c) menumjukkan berbeda nyata ( $\alpha=5 \%)$

Gambar 4.2 Histogram nilai rata-rata tekstur elastisitas sampel mie basah

Berdasarkan teori tersebut, dapat dinyatakan bahwa adanya pengaruh substitusi ekstrak abu sabut kelapa terhadap tingkat kekenyalan mie basah. Semakin tinggi ekstrak abu sabut kelapa yang disubstitusikan, semakin tinggi pula tingkat kekenyalan yang dihasilkan.

\section{Aktivitas Air $\left(\mathrm{A}_{\mathrm{w}}\right)$}

Mie basah yang memiliki $A_{w}$ tinggi memiliki kecenderungan cepat rusak yang lebih besar. Bakteri umumnya tumbuh dan berkembang biak hanya dalam media dengan nilai $\mathrm{A}_{\mathrm{w}}$ tinggi yaitu $0,91-0,99$; khamir membutuhkan nilai $\mathrm{A}_{\mathrm{w}}$ 0,87-0,91; dan kapang membutuhkan nilai $A_{w}$ yang paling rendah dari semuanya yaitu $0,80-0,87$.

Kandungan-kandungan yang terdapat pada abu sabut kelapa diduga membantu mengikat air sehingga adanya sejumlah air yang bebas bisa diminimalisir. Menurut Winarno (1997) soda abu atau natrium karbonat anhidrida mempunyai sifat mudah larut dalam air. Menurut Mappiratu (1985) yang menyatakan bahwa apabila abu dilarutkan dalam air maka sebagian unsur yang terkandung di dalamnya akan larut dan dapat dipisahkan berdasarkan sifat kelarutannya dalam air.

Dengan jumlah air yang tidak terikat semakin sedikit, maka jumlah air bebas yang dapat digunakan oleh mikroba tersebut juga semakin sedikit. Dengan demikian maka mikroba yang tumbuh dalam mie basah bisa ditekan, pertumbuhan mikroba menjadi terhambat dan tidak optimal.

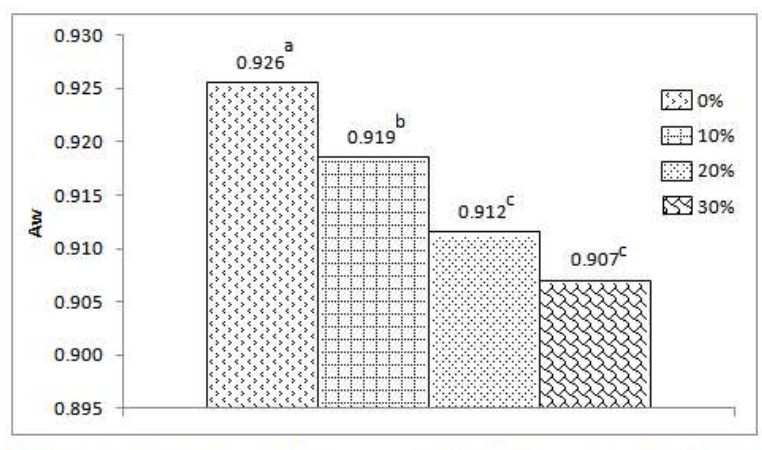

Keterangan : Angka-angka pada diagram yang diikuti huruf superscript berbeda (a, b, dan c) menunjukkan berbeda nyata $(\alpha=5 \%)$

Gambar 4.3 Histogram nilai rata-rata $\mathrm{A}_{w}$ sampel mie basah

\section{Derajat Keasaman $(\mathrm{pH})$}

Berdasarkan Gambar 4.4, derajat keasaman $(\mathrm{pH})$ mie mengalami penurunan selama penyimpanan dua hari. Sampel kontrol memiliki pH pada jam ke 0,24 , dan 48 secara berturut-turut sebesar 8,$79 ; 8,60$; dan 6.78. Sampel dengan substitusi $10 \%$ pada jam ke 0, 24, dan 48 memiliki $\mathrm{pH}$ sebesar 8,$96 ; 8,77$; dan 7,53 . Sampel substitusi $20 \%$ memiliki pH pada jam ke 0,24 , dan 48 secara berturut-turut sebesar 9,06;8,82; dan 7,86. Sedangkan sampel substitusi $30 \%$ memiliki $\mathrm{pH}$ pada jam ke 0, 24, dan 48 sebesar 9,23; 8,99 ; dan 8,30 .

Menurut Rosyid et al (2011) bakteri pembusuk yang terdapat pada mie basah yang telah teridentifikasi terdiri dari bakteri gram positif maupun gram negatif. Strain bakteri gram positif antara lain B.pumilus, C.agropyri, S.sciuri, C.urealyticum dan C.jeikeium. Sedangkan bakteri gram negatif antara lain E.cloaceae, P.aeruginosa dan S. marcescens. Sedangkan menurut Christensen (1974) bakteri yang terdapat pada mie basah diduga berasal dari bahan baku pembuatan mie basah yaitu tepung terigu. Bakteri tersebut antara lain Pseudomonas sp., Micrococcus sp., Lactobacillus sp. serta beberapa spesies Achromobacterium $s p$. Kapang yang ditemukan pada tepung terigu antara lain berasal dari genus Aspergillus, Rhizopus, Mucor, Fusarium, dan Penicillium. Selain itu, mikroorganisme yang tumbuh pada mie kemungkinan juga berasal dari air yang digunakan dalam pembuatan mie basah. Mikroorganisme tersebut adalah Bacillus sp, danClostridium sp.Mikroba-mikroba tersebut dapat tumbuh optimal pada pH 6-7 (Alcamo, 1983). 


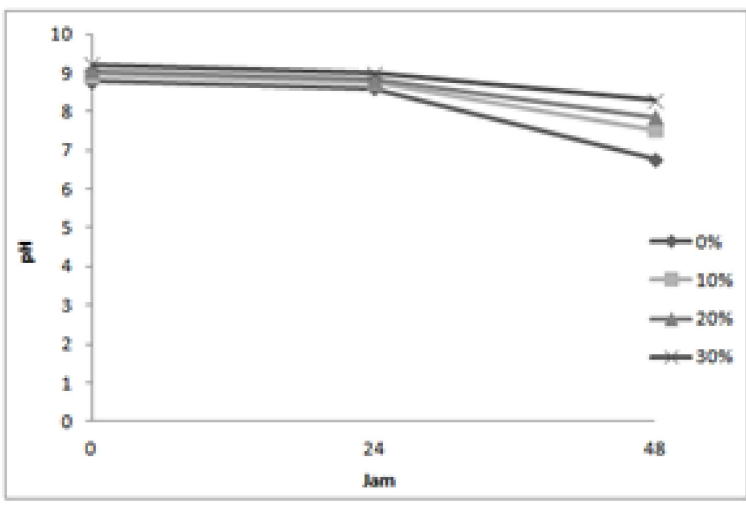

Gambar 4.4 Grafik nilai rata-rata pH sampel mie basah

Berdasarkan data tersebut membuktikan bahwa kadar ekstrak abu sabut kelapa yang disubstitusikan ke dalam formulasi mie basah memiliki pengaruh terhadap nilai $\mathrm{pH}$ mie basah dari jam ke-0 sampai jam ke-48. Sampel mie basah kontrol mengalami penurunan $\mathrm{pH}$ yang signifikan. Namun sampel substitusi $30 \%$ memiliki $\mathrm{pH}$ yang cenderung stabil. Ini berarti bahwa semakin tinggi kadar ekstrak abu sabut kelapa yang ditambahkan dapat menghambat aktivitas mikroba dan mempertahankan laju penurunan $\mathrm{pH}$ mie basah. Sehingga kerusakan mie basah dapat dihambat.

Penggunaan senyawa natrium karbonat dan kalium karbonat sebagai tambahan pada mie basah mengakibatkan $\mathrm{pH}$ lebih tinggi yaitu pH 8,0-8,5. Menurut Anonim (1987) menyatakan bahwa komponen-komponen dalam larutan alkali seperti $\mathrm{Na}_{2} \mathrm{CO}_{3}$ dan $\mathrm{K}_{2} \mathrm{CO}_{3}$ sangat berperan dalam menentukan mutu mie instant yaitu sebagai pengatur $\mathrm{pH}$.

$\mathrm{Na}_{2} \mathrm{CO}_{3}$ dan $\mathrm{K}_{2} \mathrm{CO}_{3}$ yang terurai dalam air membentuk senyawa basa kuat. Asam karbonat $\left(\mathrm{H}_{2} \mathrm{CO}_{3}\right)$ merupakan asam lemah yang terbentuk sebagai hasil reaksi karbon dioksida dan air yang berfungsi sebagai buffer/larutan penyangga yang dapat mempertahankan $\mathrm{pH}$ agar tetap setabil. Mie basah dengan substitusi ekstrak abu sabut kelapa memiliki pH yang cukup stabil, berkisar pada rentang $\mathrm{pH}$ 8-9.

Mikroba-mikroba pada mie basah dapat tumbuh optimal pada $\mathrm{pH}$ 6-7. Mie basah dengan substitusi ekstrak abu sabut kelapa memiliki $\mathrm{pH}$ yang cukup stabil, berkisar pada rentang $\mathrm{pH}$ 8-9. Kondisi $\mathrm{pH}$ basa ini menyebabkan pertumbuhan mikroba dalam mie basah tidak optimal. Laju pertumbuhan mikroba dapat dihambat, sehingga dapat mencegah kerusakan mie basah (Christensen, 1974).

\section{Mutu Mikrobiologis}

Berdasarkan Gambar 4.5 jumlah mikroba sampel kontrol pada jam ke-0, 24, dan 48 sebesar 2,65; 5,69; dan 6,89 log CFU/g. Jumlah mikroba sampel substitusi $10 \%$ pada jam ke- 0,24 , dan 48 sebesar 2,53; 5,58; dan 6,77 log CFU/g. Jumlah mikroba sampel substitusi $20 \%$ pada jam ke- 0 , 24, dan 48 sebesar 2,44; 5,38; dan 6,66 log CFU/g. Sedangkan jumlah mikroba sampel substitusi $30 \%$ pada jam ke-0, 24, dan 48 sebesar 2,22; 4,95; dan 6,59 log CFU/g. Jumlah mikroba

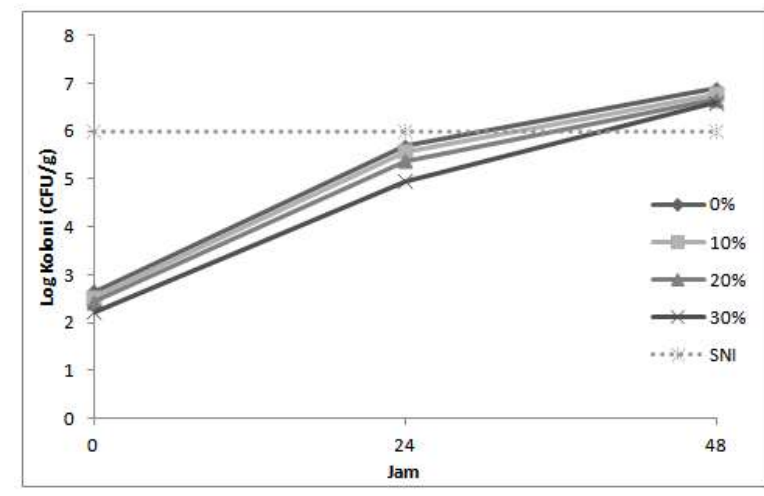

Gambar 4.5 Grafik aktivitas mikroba pada sampel mie basah

pada mie basah dengan substitusi ekstrak abu sabut kelapa lebih sedikit daripada mie basah kontrol. Hal ini menunjukkan bahwa ekstrak abu sabut kelapa dapat menghambat laju pertumbuhan mikroba.

Mie basah dengan perlakuan substitusi ekstrak abu sabut kelapa memiliki rentang $\mathrm{pH}$ 8-9. Senyawa $\mathrm{Na}_{2} \mathrm{CO}_{3}$ dan $\mathrm{K}_{2} \mathrm{CO}_{3}$ yang terdapat pada abu sabut kelapa ini diduga mampu mempertahankan $\mathrm{pH}$ pada kondisi basa, dan dapat menurunkan $A_{w}$ dengan mengikat air bebas, sehingga $A_{w}$ yang digunakan mikroba untuk tumbuh lebih sedikit. Pertumbuhan mikroba menjadi tidak optimal sehingga laju pertumbuhan mikroba dapat dihambat.

Berdasarkan data tersebut disimpulkan bahwa semakin banyak ekstrak abu sabut kelapa yang disubstitusikan dalam mie basah, maka semakin besar kemampuannya untuk menghambat laju pertumbuhan mikroba, sehingga dapat memperpanjang umur simpan mie basah. 


\section{KESIMPULAN}

Mie basah kontrol memiliki tingkat kekerasan tertinggi yaitu sebesar 10083,940 gforce; sedangkan mie basah dengan substitusi ekstrak abu sabut kelapa 30\% memiliki tingkat kekerasan terendah yaitu sebesar 7852,300 gforce. Nilai elastisitas rata-rata sampel mie basah kontrol memiliki tingkat elastisitas yang paling rendah yaitu sebesar 12,355 gforce, sedangkan sampel mie basah dengan substitusi ekstrak abu sabut kelapa $30 \%$ memiliki tingkat elastisitas paling tinggi yaitu sebesar 21,570 gforce.

Sampel mie basah dengan substitusi ekstrak abu sabut kelapa 30\% memiliki $\mathrm{A}_{\mathrm{w}}$ 0,907. Kondisi $A_{w}$ yang rendah dapat membantu menekan pertumbuhan mikroba pada mie basah. Sampel mie basah dengan substitusi ekstrak abu sabut kelapa 30\% memiliki $\mathrm{pH}$ pada jam ke 0,24 , dan 48 sebesar 9,23; 8,99; dan 8,30. Kondisi $\mathrm{pH}$ basa membantu menekan pertumbuhan mikroba pada mie basah yang tumbuh optimal pada $\mathrm{pH}$ 6-7.

Jumlah mikroba sampel substitusi $30 \%$ pada jam ke-0, 24, dan 48 sebesar 2,22; 4,95; dan 6,59 $\log \mathrm{CFU} / \mathrm{g}$. Jumlah mikroba pada mie basah dengan substitusi ekstrak abu sabut kelapa lebih sedikit daripada mie basah kontrol. Hal ini menunjukkan bahwa ekstrak abu sabut kelapa dapat menghambat laju pertumbuhan mikroba dengan menekan $\mathrm{A}_{\mathrm{w}}$ dan mengatur $\mathrm{pH}$ pada kondisi basa, sehingga pertumbuhan mikroba tidak optimal.

\section{DAFTAR PUSTAKA}

Agra IB. 1974. Pemanfaatan Senyawaan Kalium dari Abu. Yogyakarta: Bagian Teknik dan Kimia, Fakultas Teknik, Universitas Gadjah Mada.

Alcamo, I.E. 1983. Fundamentals of Microbiology. Addison-Wesley Publishing Company Inc. Massachusetts.

Anonim. 1987. Standard Industri Indonesia. Departemen Perindustrian. Jakarta.

Astawan, M. 1999. Membuat Mie dan Bihun. Penebar Swadaya. Jakarta.
Astawan, M. 2006. Mengenal Formalin dan Bahayanya. Penebar Swadaya. Jakarta.

Badan Pusat Statistik. 2002. Statistik Industri Besar dan Sedang. Badan Pusat Statistik. Jakarta.

Badan Pusat Statistik. 2004. Pengeluaran untuk Konsumsi Penduduk Indonesia. Badan Pusat Statistik, Jakarta.

Badrudin, C. 1994. Modifikasi Tepung Ubi Kayu (Manihot esculenta Crantz) sebagai Bahan Pembuat Mie Kering. Skripsi. Fakultas Teknologi Pertanian. Institut Pertanian Bogor. Bogor.

Christensen, C. M. 1974. Storage of Cereal Grains and Their Products. American Association of Cereal Chemistry. Minnesota.

Hoseney, R. C. 1998. Principles Cereal Science and Technology. Second Edition. American Association of Cereal Chemistry. Inc. Minnesotta.

Kruger, James E dan Robert B. Matsuo. 1996. Pasta and Noodle Technology. American Association of Cereal Chemist, Inc. Minnesota.

Oktaviani. 2005. Perubahan Karakteristik dan Kualitas Protein pada Mie Mentah yang Mengandung Formaldehide dan Boraks. Skripsi. Fakultas Teknologi Pertanian. Institut Pertanian Bogor. Bogor.

Pahrudin. 2006. Aplikasi Bahan Pengawet untuk Memperpanjang Umur Simpan Mi Basah Matang. Skripsi. Fakultas Teknologi Pertanian. Institut Pertanian Bogor Bogor.

Polii, Fahri F. 2003. Pemanfaatan abu pembakaran sabut kelapa pada proses pengasapan kopra menjadi soda abu sebagai bahan tambahan makanan. Balai industri pertanian sulawesi utara. Manado.

Putra, Adi. 2007. Aplikasi Kombinasi Bubuk Fuli Pala (Myristica fragrans Houtt) dan $\mathrm{NaCl}$ Sebagai Pengawet Alami pada Mi Basah Matang. Skripsi. Fakultas 
Teknologi Pertanian. Institut Pertanian Bogor. Bogor.

Rosyid, T. A., Roselina K., Noranizan M. A., and Farinazleen M. G. 2011. Antibacterial Activity of Several Malaysian Leaves Extracts on The Spoilage Bacteria of Yellow Alkaline Noodles. African Journal of Microbiology Research Vol. 5(8), pp. 898-904. Malaysia.

Winarno, F. G. 1997. Kimia Pangan dan Gizi. Gramedia Pustaka Utama. Jakarta. 